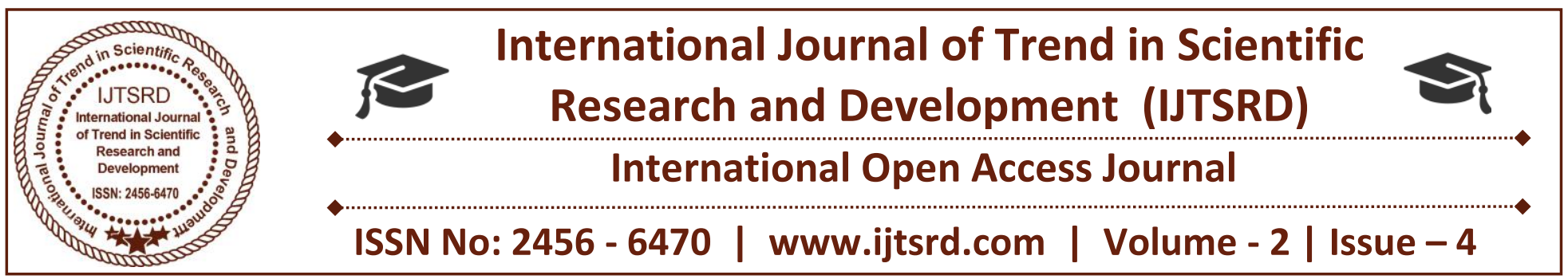

\title{
A Study on Performance of Commodities Derivatives Trading in India
}

\author{
${ }^{1}$ Dr. S. P. Dhandayuthapani, ${ }^{2}$ Hari Sudha \\ ${ }^{1}$ Assistant Professor, ${ }^{2}$ Final year PG student \\ 1,2 Department of Management studies, Anna University (BIT Campus), \\ Tiruchirapalli, Tamil Nadu, India
}

Abstract-- Ever since the first light of development commodities trading has become an integral part in the lives of mankind. Derivatives are a best financial instrument which helps investors to mitigate risk. The term commodity refers to a physical substance such as food, grains and metals which is interchangeable with another product of the same type, and which investors buy or sell, usually through future contracts. The price of the commodity is subject to supply and demand. Over the years commodities markets have been confronting tremendous progress, which is obvious from the fact that the trade in this section is existing as the boon for the global economy today. The commodity trading has been regulated by commodity exchanges and forward market commission .The major objective of this study is to figure out the trading practices and level of performance with special reference to one of the major commodity exchange in India, that is Multi Commodity Exchange (MCX). The challenging nature of these markets has made them an attractive investment avenue for investor's economy. Indian commodity derivatives market has been rationalized in 2003 and futures contracts trading has seen upturn in terms of volume and value surge with very swift growth during that decade. It raised itself to compete in the global market with international giants, such as NYMEX, CBOT, LME, etc., and became the top fifth exchange in terms of number of contracts in gold, second in silver, copper and natural gas. It is found that the trading in commodity derivatives is about three times more than in physical market, whereas, it is more than ten times in advanced economies.

Key words-- Commodities, Derivatives, Futures, Trading, Multi Commodity Exchange (MCX)

\section{INTRODUCTION}

Commodity derivatives market in India seems like old wine in new bottle. In reality, forward trading in commodities existed in India from ancient times (period of Kautilya's Arthasastra) and the first modern futures market was established in 1875 for cotton contracts by the Bombay Cotton Trade Association, just a decade after CBOT entered the focus and traded its first future. The separate association Bombay Cotton Exchange Ltd was established over widespread discontent amongst leading cotton mill owners and merchants over the functioning of the Bombay Cotton Trade Association. The movement continued by setting up "Gujarath Vyapar Mandali" in 1900 for futures trading in oil seeds, ground nut, castor seed and cotton seeds etc. The chamber of commerce at Harpur established the futures exchange for wheat trading in 1913, the first futures exchange for bullion futures in Mumbai in 1920 and similar exchanges come up in Rajkot, Jamnagar, Kanpur, Delhi and Calcutta. In Calcutta Hessain Exchange Ltd in 1919 and East Indian Jute Association Ltd in 1927 were established further and these two exchanges merged in 1945 as East India Jute and Hessin Ltd to conduct the organized trading of futures contracts in raw jute and related goods, meanwhile, many other exchanges started in country to trade in diversified commodities.

After independence, Government of India commissioned a committee headed by A D Shroff in 1950 to introduce Forward Contract bill in Parliament, under the regulation of Ministry of Consumer Affairs and Public Distribution. The FMC was powered to regulate, licensing and Control of trading of forward and option contracts all over India. The smooth 
functioning of Market continued till 1966, but due to various regulations, the market lost its vivacious and finally the forward trading was completely banned. The Government of India reintroduced forward trading in select commodities like Cotton, Jute, Potato, etc., as per the recommendation of Khusro Committee in 1980. Subsequently, the liberalization of Indian economy in 1991 gave a new lease of life for commodity trading. The Government setup a new committee under the chairmanship of Prof. K. N. Kabra in 1993, the committee recommended to start the futures trading in agriculture commodities in basmati rice, cotton seed, oilseeds, etc. Further in 1996, the World Bank in association with United Nations Conference on Trade and Development (UNTCAD) conducted a feasibility study and found that there is tremendous scope in revitalizing futures trading. In 2000, National Agricultural policy envisioned the reforms in agricultural commodities trading, that has brought a new wave in trading of commodity futures and paved the path for hedging and risk management by removal of control and regulation in agricultural market. In the aftermath of the second generation reforms, based on the recommendations of Kabra committee, World Bank Report and Guru Committee (2001) brought a dimension futures trading in Indian commodity market.

India has six national commodity exchanges namely, Multi Commodity EXchange (MCX), National Commodity and Derivatives EXchange (NCDEX), National Multi Commodity EXchange (NMCE), Indian Commodity EXchange (ICEX), The ACE Derivatives exchange (ACE) and the Universal Commodity EXchange (UCX). The regulatory body is Forward Markets Commission (FMC) which was set up in 1953.As of September 2015 FMC was merged with the Securities and EXchange Board of India (SEBI)

The commodities that are traded today are:

1. Precious Metals: Gold, Silver, Platinum, etc.

2. Other Metals (Base Metals): Nickel, Aluminum, Copper, etc.

3. Agro-Based Commodities: Wheat, Corn, Cotton, Oils, Oilseeds, etc.

4. Soft Commodities: Coffee, Cocoa, Sugar, etc.

5. Live- Stock: Live Cattle, Pork Bellies, etc.

6. Energy: Crude Oil, Natural Gas, Gasoline, etc.

\section{LITERATURE REVIEW}

Dharmbeer and Mr. Barinder Singh (2011) "IndianCommodity Market: Growth and Prospects" summarizes theoretical and empirical research on the growth and prospects of emerging commodity markets and the re-sulting implication on policy and regulation. They found from the previous studies that derivatives markets have supported the hedging role of emerging derivatives markets. All commodities are globally traded and the global demand-supply situation is widely known and available to anyone who reaches out for it. The commodity markets are nowhere as volatile as stock futures. Since commodity exchanges promote price transparency, he refuses to buy the story that commodity exchange fuel inflation.

Sunil Kumari (2011) in his research paper "An Insight into Derivative Market: Indian Perspective" attempted to study is the genesis of derivatives trading by tracing its historical developments, types of traded derivatives products, regulation and policy developments, trend and growth, futures prospects and challenges of derivative market in India. Derivatives market should be developed in order to keep it at par with other derivative markets in the world. They found RBI should play a greater role in supporting derivatives and SEBI should conduct seminars regarding the use of derivatives to educate individual investor. So, SEBI should take necessary steps for improvement in Derivative Market so that more investors can invest in Derivative market.

Dr. G. Selvalakshmi and Dr. A. Arumugam (2014) "Impact of Price Level Change in Indian Commodity Market" asserts that since its reintroduction, the commodity derivatives market is thriving and the current trend shows the strong growth potential of the market, although, the actual growth trajectory will depend upon the attitude of the policy makers and the efficiency of the regulatory mechanism.

Sumit Gupta (2008) explains the economic functions of the commodity futures market, regulations of the commodity derivative market and the present scheme of regulation in Indian commodity derivatives market and the economic functions of the commodity futures market includes market creation by entering into futures contract. The regulation of commodity market is required to ensure that market efficiently performs the twin economic functions of price discovery and price risk management to properly integrate spot and futures prices, to provide protection against risk of volatility in prices. 
Kamal Nayan Kabra (2007) in his research "Commodity Futures in India" concluded that in short span of time, the commodity futures market has achieved exponential growth in turnover. He found various factors that need to be consider for making commodity market as an efficient instrument for risk management and price discovery and suggested that policy makers should consider specific affairs related with agricultural commodities marketing, export and processing and the interests involved in their actual production.

Dr. Sunitha Ravi (2013) in her research paper studied the "Price Discovery and Volatility Spillover in Indian Commodity Futures Markets Using Selected Commodities". The results of the research study indicate that the future market of the commodities is more efficient as compared to spot market. The future market also helps spot market in the process of Price Discovery. She found that the derivative instruments are available for the underlying commodities significantly influence the volatility.

\section{OBJECTIVES OF THE STUDY}

1) To examine the need of Commodity Derivative in India

2) To study the history and evolution of Indian Commodity Market.

3) To study the different forms of investing in Indian commodity markets.

4) To study the different segments of Indian Commodity Markets.

5) To analyze the regulatory framework of commodity market in India.

6) To study the challenges as faced by commodity market in India

\section{A. Need of the study}

1. The need of the study arise due to lack knowledge about the commodity market because now a days commodity trading has important avenue and most of the investors are still unaware about its advantages and shortcomings.

2. Huge amount of investment is required for trading in commodity market.

3. To know the impact of other markets on commodity market, it became necessary to understand the trading of commodity market. Such an analysis will help the investor to invest in commodity market.

\section{RESEARCH METHODOLOGY}

The present study is conducted on commodity futures market in India. The study is descriptive in nature. The literature and data are mainly based on secondary source, which has been collected from commodity market and their various publications, text books related topics, magazines, reputed journals, research paper \& various internet sources like www.mcxindia.com, and other publications. The various reports and records issues and maintained by the Government of India (GOI) are also used in the study. This study is based on current scenario of commodity futures market in India \& its policies and designed to gather descriptive information's. There is no tool applied to values and volumes fluctuations of commodity market.

Tools used:

1) Tables

2) Charts

Techniques used:

\section{1) Augmented Dickey-Fuller (ADF) test}

\section{2) Error correction model}

The Augmented Dickey-Fuller (ADF) test consists of estimating the following regression (for the purpose of testing stationarity.)

$$
\Delta Y_{t}=\beta_{1}+\beta_{2} t+\delta Y_{t-1}+\sum_{i=1}^{m} \alpha_{i} \Delta Y_{t-1}+\varepsilon_{t}
$$

If on the basis of the above test time series is found to be non stationary it is transformed by differencing and made stationary.

Transforming Non Stationary Time Series

A non stationary time series may be transformed to stationary time series by taking its first difference. The new series of differenced data will be:

$$
\Delta X_{t}=X_{t}-X_{t-1}
$$

If a time series is to be transformed dimes to make it stationary the series is said to be integrated of order $d$, for example if a series is to be transformed once to make it stationary it is said to be integrated of order one.

\section{Error Correction Model}


For a two variable system a typical error correction model would relate the change in one variable to past equilibrium errors, as well as to past changes in both variables. A long term relationship between two or more variables is given by a cointegrating relationship, if it exists. On its own, a cointegrating relationship sheds no light on short-term dynamics, but its very existence indicates that there must be some short term forces that are responsible for keeping the relationship intact, and thus that it should be possible to construct a more comprehensive model that combines short-run and long-run dynamics. This is the objective of an error correction model. The error correction model (ECM) for cointegrated variables is commonly interpreted as reflecting partial adjustment of one variable to another. The concepts of cointegration and error correction are closely related. Indeed, it has been proven that two variables which are cointegrated have an error correction model representation. An error correction model for two variables relates the changes in the variables to lagged changes and a lagged linear combination of levels. The linear combination of levels which enters the error correction model is just that combination which is stationary in levels. In other words, when two variables are cointegrated, there always exists a valid error correction model for the data. An error correction model can be thought of as a description of the process by which the variables eliminate or correct the equilibrium error. Temporal causality can be assessed by examining the statistical significance and relative magnitudes of the error correction coefficients and the coefficients on lagged variables.

The error correction model for the present study can be written as:

$$
\begin{aligned}
\Delta F_{t} & =\delta_{f}+\alpha_{f} \hat{u}_{t-1}+\beta_{f} \Delta S_{t-1}+\gamma_{f} \Delta F_{t-1}+e_{f, t} \\
\Delta S_{t} & =\delta_{s}+\alpha_{s} \hat{u}_{t-1}+\beta_{s} \Delta F_{t-1}+\gamma_{s} \Delta S_{t-1}+e_{s, t}
\end{aligned}
$$

Each of the above equations can be interpreted as having two parts. The first part (ût-1) is the equilibrium error. This measures how the left hand side variable adjusts to the previous period's change in price on current period's deviation. The coefficient of the equilibrium error $\boldsymbol{\alpha}$ f and $\boldsymbol{\alpha s}$ are the speed of adjustment coefficient and have important implication in error correction model. At least one speed of adjustment coefficient must be non zero for the model to be ECM. The coefficient serves the role of identifying the direction of causal relation and shows the speed at which departure from equilibrium is corrected. If $\boldsymbol{\alpha}$ f is statistically insignificant, the current period's change in futures price does not respond to last period's deviation from long run equilibrium. If both $\alpha \mathrm{f}$ and $\beta \mathrm{f}$ are statistically insignificant; the spot price does not Granger cause futures price.

Table 1: Category wise global Derivatives volume (in billion contracts)

\begin{tabular}{|l|r|r|r|}
\hline Category & CY 2015 & CY 2016 & \% Change \\
\hline Equity Index & 8,340 & 7,117 & -14.7 \\
\hline Individual Equity & 4,945 & 4,557 & -7.8 \\
\hline Interest Rates & 3,251 & 3,515 & 8.1 \\
\hline Currency & 2,797 & 3,078 & 10.0 \\
\hline Agriculture & 1,411 & $\mathbf{2 , 2 1 4}$ & 56.9 \\
\hline Energy & 1,640 & 1,932 & 17.8 \\
\hline Precious Metals & 316 & 312 & -1.4 \\
\hline Non-Precious Metals & 1,281 & $\mathbf{1 , 8 7 7}$ & 46.6 \\
\hline Others & $\mathbf{8 2 0}$ & 616 & -24.9 \\
\hline Total & $\mathbf{2 4 , 8 0 1}$ & $\mathbf{2 5 , 2 2 0}$ & $\mathbf{1 . 7}$ \\
\hline
\end{tabular}

Agricultural derivatives witnessed strong growth, with volumes rising $56.9 \%$ to 3.5 billion contracts in 2016.while non - precious metals volumes surged $46.6 \%$ to 1.8 billion contracts, energy volume rose $17.8 \%$ to 1.9 billion contracts in 2016.(table 1) 


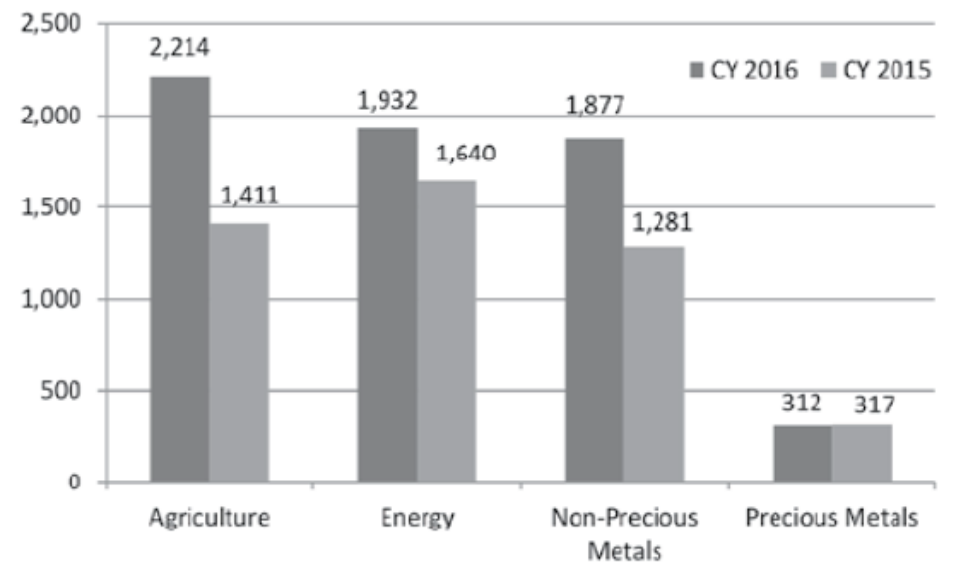

Source: 2016 FIA Annual Volume Survey, March 2017

Figure 1: category wise global commodity derivatives volume (in million contracts)

Overall in 2016, commodity derivatives remained the next most traded category after equity indices derivatives trading, well-above derivatives trading in interest rates, currencies and others (fig 1)

\section{Industry structure and development}

Volume growth in the Indian commodity derivatives market moderated by $3 \%$ in 2016-17. The total Value of commodity futures traded by all national commodity exchanges was Rs 64.91 trillion in the year, as against Rs 66.83 trillion in the previous year.

\section{Inferences:}

As evident from the continued growth of the Indian economy, as well as continued reforms being witnessed in the commodity derivatives market, your Company sees a number of opportunities which can be reaped as and when they present themselves. A number of these opportunities have arisen from policy action directed at the growth and development of the commodity derivatives market. While presenting the Union Budget for 2017-18, the Hon'ble Finance Minister announced the setting up of an expert committee to study and promote the creation of an operational and legal framework to integrate spot market and derivatives market in the agricultural sector. This is a major opportunity for your Company as this can usher in the benefits of electronic markets for commodities to all stakeholders. More significantly, the Union Budget also indicated the integration of the commodities and securities derivative markets by "integrating the participants, brokers and operational frameworks." It is expected that the integration of participants would ease the introduction of new participant classes such as financial institutions in commodity derivatives market.
The introduction of Goods and Service Tax (GST) is a significant step in the field of indirect tax reforms in India. It can have several positive ramifications for the commodity markets by making the markets more relevant to stakeholders spread across the nation. GST envisages a "One India - One Tax - One Market" and with removal of differential state specific taxes, a larger pan-India market for commodities can be created. This will enable seamless transportation of commodities across state borders, help in building efficient linkages between the spot and derivatives markets and enhance the relevance of exchange discovered prices to the entire trading ecosystem. It would connect the exchanges delivery with more buyers from across the nation as the logistics improve and help in setting up additional delivery centers, thus giving a boost to derivatives trading in commodities. In the case of bullion, for instance, GST on gold bars/jewellery has been fixed at $3 \%$ against the present $2.2 \% \quad(1 \%$ excise \& $1.2 \%$ VAT in Maharashtra). Currently, there is no VAT (rate varies from state to state) set off in case of interstate transfer of Gold/ Silver. Set off is available only if it is transacted within the same state. The GST regime will facilitate a smooth flow of tax credit and uniformity in tax will permit easy movement of gold from the place of delivery to the destination. Credit of input tax, being the crux of GST initiative, will ensure wider inclusion of tax payers in the supply chain. Under invoicing will be disincentives. The chain from primary sellers to the final consumers will leave little room for tax evasion leading to increase in the share of organized participants. Your Company sees this as an opportunity for the growth and development of its bullion derivative product suite. 


\section{CONCLUSION}

The development of commodity market is significant during last decade. Prices of all commodities are heading northwards due to rapid increase in demand for commodities. Developing countries like China are rapaciously consuming the commodities. That's why globally commodity market is bigger than the stock market. It is the market where a wide range of products, viz., precious metals, base metals, crude oil, energy and soft commodities like palm oil, coffee etc. are being traded. It is important to develop a vibrant, active and liquid commodity market. This would help investors hedge their commodity risk, take speculative positions in commodities and exploit arbitrage opportunities in the market. Value of contracts traded in commodity market represents the demand for trading and the people awareness regarding market. The inverse relation of commodity market with stock market shows the alternative ahead investors whenever they feel bearish trend in the same.

\section{References}

[1] Derivatives and Risk Management by Dr.R.P.Rustagi edition 2014.

[2] Derivatives principle and practice by Sundaram Das Mc Graw Hill Education Indian edition

[3] Sharma, Dr.Tanushree "An Empirical Analysis of Commodity Future Market in India” International Journal of Engineering Technology, Management and Applied sciences .

[4] Engle, R. 2001. GARCH 101: The Use of ARCH/GARCH models in Applied Econometrics. Journal of Economic Prospective, 15(4): p. 157.

[5] Bhaskar Goswami ,Isita Mukherjee "Risk Return analysis of different commodity futures in Indian derivative market ". International Journal of Research in Finance and Marketing June 2015 7378.

[6] Dr.S.P.Dhandayuthapani, K.Dhineshini "Price Discovery Mechanism of Spot and Futures Market in India : A Case of selected Agri Commodities " International Journal for Innovative Research in Science and Technology (2016) : 258-262. 